\title{
Estimation of the incidence of invasive meningococcal disease using a capture-recapture model based on two independent surveillance systems
}

Pilar Ciruela ( $\sim$ pilar.ciruela@gencat.cat)

Public Health Agency of Catalonia (ASPCAT)

Marta Vilaró

Universitat de Barcelona

Gloria Carmona

Public Health Agency of Catalonia (ASPCAT)

Mireia Jané

Public Health Agency of Catalonia (ASPCAT)

Núria Soldevila

Universitat de Barcelona

Tomás Garcia

Public Health Agency of Catalonia (ASPCAT)

Sergi Hernández

Public Health Agency of Catalonia (ASPCAT)

Laura Ruiz

Public Health Agency of Catalonia (ASPCAT)

Angela Domínguez

Universitat de Barcelona

\section{Research Article}

Keywords: Meningococcal disease, Capture-recapture, estimated incidence, surveillance systems

Posted Date: May 14th, 2021

DOI: https://doi.org/10.21203/rs.3.rs-500408/v1

License: @) (1) This work is licensed under a Creative Commons Attribution 4.0 International License. Read Full License 


\section{Abstract}

Background: Invasive meningococcal disease (IMD) is an urgent notifiable disease and its early notification is essential to prevent cases. The objective of the study was to assess the sensitivity of two independent surveillance systems, the statutory disease reporting system (SDR) and the microbiological reporting system (MRS), and to estimate the incidence of IMD.

Methods: The study was performed in Catalonia, Spain, between 2011 and 2015. The variables collected were age, sex, year of report, size of municipality (< 10,000 and $\geq 10,000$ ), clinical form, death, serogroup, country of birth and type of reporting centre (private and public). The capture-recapture analysis and $95 \%$ confidence intervals were calculated using the Chapman formula. Multinomial logistic regression was performed for adjusted estimation.

Results: The sensitivity of the two combined surveillance systems was $88.5 \%$ (85.0-92.0). SDR had greater sensitivity than the MRS (67.9\%; $62.7-73.1$ vs. $64.7 \% ; 59.4-70.0)$. In 2014-2015, the sensitivity of both systems was higher (80.6\%; 73.2-87.9 vs. 73.4\%; 65.2-81.6) than in $2011-2013$ (59.3\%; $52.6-66.0$ vs. $58.3 \%$; $51.6-65.1)$. In private centres, the sensitivity was higher for SDR than for MRS $(100 \% ; 100-100$ vs. 4.8\%; $-4.4-13.9)$. The adjusted estimate of cases was lower than that obtained using the Chapman formula $(279 ; 266-296$ vs. $313 ; 295-330)$. The estimated adjusted incidence of IMD was $0.7 / 100,000$ persons-year.

Conclusions: The sensitivity of enhanced surveillance through the combination of two complementary sources was higher than for the sources individually. Factors associated with under-reporting in different systems should be analysed to improve IMD surveillance.

\section{Background}

Invasive meningococcal disease (IMD) continues to be an important cause of morbidity and mortality, mainly in children aged < 4 years and adolescents. [1]

In the European regions, the incidence rate of confirmed IMD cases is around 0.6/100,000 persons, [2] similar to Spain (0.58/100,000 persons). [3] The highest incidence is for meningococcal serogroup $B$, accounting for $51.5 \%$ of confirmed IMD cases. The case fatality rate is around $10-15 \%$ [3, 4 ] and longterm sequelae occur in $10-20 \%$ of cases. [5]

IMD is an urgent notifiable disease and its early notification is essential to provide an adequate public health response in patients and their close contacts to prevent further cases. Epidemiological surveillance allows monitoring of the impact of public health interventions, including vaccination programmes. Therefore, a robust epidemiological and microbiological system with timely and accurate surveillance providing information on the frequency of cases and the distribution of circulating serogroups is crucial.

Evaluations of surveillance systems should be conducted regularly to increase their utility. [6-8] There are two reporting systems for the epidemiological surveillance of communicable disease in Catalonia: the statutory disease reporting system (SDR) and the microbiological reporting system (MRS). [9]

The capture-recapture method is a statistical method for estimating the real incidence of diseases in a population with two or more information sources. [10, 11] The method is valid if four conditions are met: 1 ) the population under study has to be closed, i.e., there should be no changes during the study period; 2 ) there must be a method of determining whether an individual identified by one source is the same as an individual identified by the other; 3 ) each individual must have the same probability of being captured by either system; 4) the systems must be independent.

The aim of this study was to assess the sensitivity of the two surveillance systems in Catalonia (SDR and MRS) using the capture-recapture method and to estimate the incidence of IMD.

\section{Methods Information sources}

Catalonia is a region in the northeast of Spain with a population of 7,508,106 in 2015. [12]

The SDR is a passive surveillance system through which health professionals declare all infectious diseases subject to surveillance. The reporting of cases to the Public Health Agency of Catalonia (PHAC) is mandatory and includes confirmed cases of IMD and is regulated by a Decree. [9, 13]

The MRS is a surveillance system that consists of microbiologists notifying laboratory confirmed microorganisms that cause infectious diseases. The main objectives of the MRS are to confirm suspected cases of infectious diseases through the identification of the microorganisms and serogroups involved and to determine trends and changes in epidemiological patterns and microbiological resistance. [14]

The MRS was non-compulsory until 2015 and involved 50 health care centres representing over $83 \%$ of acute hospital beds. [15] Confirmed IMD cases were reported by microbiologists including sex, age, clinical presentation, serogroup and diagnostic method.

Both systems belong to the PHAC epidemiological surveillance network and, since 2014, transfer information automatically, but the independence of the sources is maintained.

\section{Cases definition, inclusion, and exclusion criteria}


A confirmed case of IMD was defined as laboratory confirmed if at least one of the following criteria was fulfilled: isolation in cultures or detection of Neisseria meningitidis DNA by PCR in a normally sterile site, detection of gram-negative diplococci or N. meningitidis antigen in cerebrospinal fluid.

\section{Data collection}

We made a retrospective study of confirmed IMD cases in Catalonia from January 2011 to December 2015. We extracted all IMD records from the MRS and SDR and linked the databases using the personal identification code (PIC). When the PIC was not available, data on notification, age and sex were used to identify duplicates between the two sources. In cases with inconclusive matching, the hospital was used as a fifth matching criterion.

Estimates were made for the entire 5-year period and by age, sex, year of report, size of municipality $(<10,000$ and $\geq 10,000)$, country of birth, number of hospital beds, clinical form (meningitis, with or without sepsis, sepsis, and others), serogroup, death and reporting centre (private or public).

The study was not submitted for research ethics approval as the activities described were conducted as part of the legislated mandate of the Health Department of Catalonia, the competent authority for surveillance of communicable diseases according to Decree 203/2015 of the 15 September which created the epidemiological surveillance network of Catalonia. [9] All the study activities formed part of public health surveillance and did not require informed consent. Personal data were used only for the matching process and measures to protect the confidentiality of personal data were applied (access to the data restricted to the personnel involved in data analysis, and removal of personal data from the datasets after matching).

\section{Statistical methods}

The total number of IMD cases was estimated using the two-source capture-recapture method, which uses Chapman's formula, [16] developed to reduce bias due to small samples:

$$
\begin{gathered}
N=\frac{(L 1+1)(L 2+1)}{a+1}-1 \\
95 \% C I=N \pm 1.96 \sqrt{\frac{(L 1+1)(L 2+1)(L 1-a)(L 2-a)}{(a+1)^{2}(a+2)}}
\end{gathered}
$$

where L1 is the number of cases in the SDR dataset, L2 is the number of cases reported to MRS, and a is the number of cases captured by both systems. The sensitivity (Se) of case ascertainment by the two sources was also calculated as the proportion of true cases detected by each source, i.e. Se (1) = L1/N for source 1 and $\mathrm{Se}(2)=\mathrm{L} 2 / \mathrm{N}$ for source 2 . The sensitivity of bothsources combined was calculated as the proportion of cases detected by one of the two sources or both, i.e., $\mathrm{Se}(1,2)=(\mathrm{L} 1+\mathrm{L} 2-\mathrm{a}) / \mathrm{N}$.

The independence of the sources was considered when applying the capture-recapture method. $[17,18]$ In the two-by-two table, where a represents cases reported by two sources or combinations of sources, $\mathbf{b}$ and $\mathbf{c}$ cases reported exclusively by either of the two sources and $\mathbf{x}$ the estimated non-reported cases by either of the sources, the odds ratio $(\mathrm{OR}=\mathrm{ax} / \mathrm{bc})$ should not differ from one.

A multinomial logit model was used to evaluate patient characteristics and the probability of capture by different sources, which allows more precise estimates of the number of cases. $[19,20]$ We used a backwards stepwise procedure (using likelihood ratio tests, with a P-value $>0.2$ as the criterion for removing variables from the model), [21,22] starting with a full model including all potential covariates, and we used the parameter estimates from the model to estimate the sizes of population subgroups and their $95 \%$ confidence intervals $(\mathrm{Cl})$. All analyses were made using R software version 3.0 .1 .

\section{Results}

\section{Patient characteristics}

Patient characteristics by source are shown in Table 1. From 2011 to 2015, 212 IMD cases were reported to the SDR and 202 cases to the MRS, representing an incidence of 0.56 and $0.54 / 100,000$ persons-year, respectively. IMD due to serogroup B was the most-frequently reported serogroup (77.4\% and $75.7 \%$ in the SDR and MRS, respectively). Around $63 \%$ of patients were aged < 15 years; the mean age was 21.4 for the SDR and 20.5 years for the MRS. Male sex was more frequent in the SDR (52.4\%) than in the MRS (49\%). The SDR presented the most cases in 2015 (48 cases; $22.6 \%$ ) and the MRS (61 cases; $30.2 \%)$ in 2011 . The SDR reported that $84 \%$ of patients lived in a municipality of $\geq 10,000$ people compared with $73 \%$ in the MRS. In both sources, the number of cases declared in a hospital of $\geq 200$ beds were around $70 \%$. The main clinical form in both sources was meningitis (54.7\% and $64.8 \%$, respectively) and sepsis (38.7\% and $32.7 \%$, respectively). Reports from private centres represented $10 \%$ of cases in the SDR and $0.5 \%$ in the MRS. Twenty-two cases ( $10.4 \%$ ) cases reported by the SDR died compared with 11 cases (5.4\%) reported by the MRS . 
Table 1

Sociodemographic, clinical and microbiological characteristics of invasive meningococcal disease cases reported to the SDR and MRS, Catalonia 2011-2015

\begin{tabular}{|c|c|c|}
\hline & $\operatorname{SDR}(n=212)$ & MRS $(n=202)$ \\
\hline \multicolumn{3}{|l|}{ Age groups } \\
\hline Mean (SD) & $21.4(27.9)$ & $20.5(26.7)$ \\
\hline Median (IQR) & $6(36)$ & $6(32.3)$ \\
\hline <2 years, $\mathrm{n}(\%)$ & $62(29.8 \%)$ & $61(30.7 \%)$ \\
\hline $2-4$ years, $n(\%)$ & $35(16.8 \%)$ & $30(15.1 \%)$ \\
\hline 5-14 years, $n(\%)$ & $34(16.3 \%)$ & $35(17.6 \%)$ \\
\hline $15-24$ years, $n(\%)$ & $12(5.8 \%)$ & $12(6.0 \%)$ \\
\hline $25-34$ years, $n(\%)$ & $12(5.8 \%)$ & $9(4.5 \%)$ \\
\hline $35-44$ years, $n(\%)$ & $10(4.8 \%)$ & $12(6.0 \%)$ \\
\hline $45-54$ years, $n(\%)$ & $9(4.3 \%)$ & $7(3.5 \%)$ \\
\hline$>55$ years, $\mathrm{n}(\%)$ & $34(16.3 \%)$ & $33(16.6 \%)$ \\
\hline NAs & $1(0.5 \%)$ & $2(1.0 \%)$ \\
\hline \multicolumn{3}{|l|}{ Sex, n (\%) } \\
\hline Male & $111(52.4 \%)$ & $99(49.0 \%)$ \\
\hline Female & $101(47.6 \%)$ & $103(51.0 \%)$ \\
\hline \multicolumn{3}{|l|}{ Year of report, n (\%) } \\
\hline 2011 & $43(20.3 \%)$ & $61(30.2 \%)$ \\
\hline 2012 & $41(19.3 \%)$ & $29(14.4 \%)$ \\
\hline 2013 & $38(17.9 \%)$ & $30(14.9 \%)$ \\
\hline 2014 & $42(19.8 \%)$ & $34(16.8 \%)$ \\
\hline 2015 & $48(22.6 \%)$ & $48(23.8 \%)$ \\
\hline \multicolumn{3}{|c|}{ Size of municipality, n (\%) } \\
\hline$<10,000$ people & $27(12.7 \%)$ & $28(13.9 \%)$ \\
\hline$\geq 10,000$ people & $177(83.5 \%)$ & $148(73.3 \%)$ \\
\hline NAs & $8(3.8 \%)$ & $26(12.9 \%)$ \\
\hline \multicolumn{3}{|c|}{ Country of birth, n (\%) } \\
\hline Spain & $194(91.5 \%)$ & $188(93.1 \%)$ \\
\hline Other countries & $18(8.5 \%)$ & $14(6.9 \%)$ \\
\hline \multicolumn{3}{|c|}{ Number of hospital beds, n (\%) } \\
\hline$<200$ & $60(28.3 \%)$ & $65(32.2 \%)$ \\
\hline$\geq 200$ & $149(70.3 \%)$ & $137(67.8 \%)$ \\
\hline NAs & $3(1.4 \%)$ & $0(0.0 \%)$ \\
\hline \multicolumn{3}{|l|}{ Clinical form, n (\%) } \\
\hline Meningitis & $116(54.7 \%)$ & $131(64.8 \%)$ \\
\hline Sepsis & $82(38.7 \%)$ & $66(32.7 \%)$ \\
\hline Other forms & $14(6.6 \%)$ & $4(2.0 \%)$ \\
\hline NAs & $0(0.0 \%)$ & $1(0.5 \%)$ \\
\hline \multicolumn{3}{|l|}{ Serogroup, $\mathrm{n}(\%)$} \\
\hline$A$ & $0(0.0 \%)$ & $2(1.0 \%)$ \\
\hline
\end{tabular}

NAs: Not available; SDR: Statutory disease reporting; MDR: Microbiological reporting system 


\begin{tabular}{|lll|}
\hline & SDR $(\mathbf{n}=\mathbf{2 1 2})$ & MRS $(\mathbf{n}=\mathbf{2 0 2})$ \\
\hline B & $164(77.4 \%)$ & $153(75.7 \%)$ \\
\hline W135 & $26(12.3 \%)$ & $21(10.4 \%)$ \\
\hline Y & $4(1.9 \%)$ & $6(3.0 \%)$ \\
\hline Y/ W135 & $5(2.4 \%)$ & $2(1.0 \%)$ \\
\hline Non-groupable & $1(0.5 \%)$ & $1(0.5 \%)$ \\
\hline NAs & $6(2.8 \%)$ & $4(2.0 \%)$ \\
\hline Type of reporting centre & $6(2.8 \%)$ & $13(6.4 \%)$ \\
\hline Private & $21(10.0 \%)$ & $201(99.5 \%)$ \\
\hline Public & $190(90.0 \%)$ & \\
\hline NAs: Not available; SDR: Statutory disease reporting; MDR: Microbiological reporting system & & \\
\hline
\end{tabular}

\section{Capture-recapture analysis}

The odds ratio $(\mathrm{OR})$ was $1.01(95 \% \mathrm{Cl} 0.62-1.66)$, reinforcing the independence of the two sources.

During the period studied, 212 and 202 IMD cases were reported by the SDR and MRS, respectively. One hundred thirty-seven cases (43.8\%) coincided in both sources and 36 cases (11.5\%) were not reported to either source. The estimated number of cases was 313 (95\% Cl 295-330) (Table 2) and the estimated incidence rate was $0.83 / 100,000$ persons-year.

Table 2

Capture-recapture analysis of two datasets to estimate the total number of invasive meningococcal disease cases,

\begin{tabular}{|lllll|}
\hline \multicolumn{5}{c}{ Catalonia 2011-2015 } \\
\hline \multirow{4}{*}{ SDR } & \\
\cline { 3 - 5 } & & Identified & Not identified & Total \\
\hline \multirow{2}{*}{ MRS } & Identified & 137 & 65 & 202 \\
\cline { 2 - 5 } & Not identified & 75 & 36 & 111 \\
\hline & Total & 212 & 101 & 313 \\
\hline \multirow{2}{*}{$\begin{array}{l}\text { SDR: Statutory disease reporting } \\
\text { MRS: Microbiological reporting system }\end{array}$} & \\
\hline
\end{tabular}

The sensitivity of the SDR was $67.9 \%(95 \% \mathrm{Cl} 62.7-73.1)$ and that of the MRS was $64.7 \%(95 \% \mathrm{Cl} 59.4-70.0)(\mathrm{P}-<0.001)($ Table 3$)$. The sensitivity increased to $88.5 \%(95 \% \mathrm{Cl} 85.0-92.0)$ when the datasets were combined. 
Table 3

Capture-recapture analysis of all invasive meningococcal disease cases reported to the SDR and MRS stratified by characteristics, Catalonia 2011-2015

\begin{tabular}{|c|c|c|c|c|c|c|c|c|c|}
\hline & $\begin{array}{l}\text { No. } \\
\text { records in } \\
\text { SDR }\end{array}$ & $\begin{array}{l}\text { No. } \\
\text { records in } \\
\text { MRS }\end{array}$ & $\begin{array}{l}\text { Matched } \\
\text { records }\end{array}$ & $\begin{array}{l}\text { Calculated } \\
\text { unreported } \\
\text { cases }\end{array}$ & $\begin{array}{l}\text { Estimated total } \\
\text { no. of cases } \\
(95 \% \mathrm{Cl})\end{array}$ & $\begin{array}{l}\text { Sensitivity } \\
\text { SDR (\%) } \\
(95 \% \mathrm{Cl})\end{array}$ & $\begin{array}{l}\text { Sensitivity } \\
\text { MRS (\%) } \\
(95 \% \mathrm{Cl})\end{array}$ & $\begin{array}{l}\text { Difference in } \\
\text { sensitivities (\%) }\end{array}$ & $\begin{array}{l}P \text { - } \\
\text { value }\end{array}$ \\
\hline All cases & 212 & 202 & 137 & 36 & $313(295,330)$ & $\begin{array}{l}67.9(62.7 \\
73.1)^{(6)}\end{array}$ & $\begin{array}{l}64.7(59.4 \\
70.0)\end{array}$ & 3.2 & $<.001$ \\
\hline \multicolumn{10}{|l|}{ Age group } \\
\hline$<15$ years & 131 & 126 & 87 & 20 & $190(177,203)$ & $\begin{array}{l}69.1(62.6 \\
75.7)\end{array}$ & $\begin{array}{l}66.5(59.8 \\
73.2)\end{array}$ & 2.6 & \multirow[t]{2}{*}{0.468} \\
\hline$\geq 15$ years & 80 & 74 & 49 & 16 & $121(109,133)$ & $\begin{array}{l}66.4(58.0 \\
74.8)\end{array}$ & $\begin{array}{l}61.4(52.7 \\
70.1)\end{array}$ & 5.0 & \\
\hline \multicolumn{10}{|l|}{ Sex } \\
\hline Male & 111 & 99 & 71 & 16 & $155(144,166)$ & $\begin{array}{l}71.8(64.7 \\
78.9)\end{array}$ & $\begin{array}{l}64.0(56.5 \\
71.6)\end{array}$ & 7.8 & \multirow[t]{2}{*}{0.588} \\
\hline Female & 101 & 103 & 66 & 20 & $158(145,171)$ & $\begin{array}{l}64.2(56.7 \\
71.7)\end{array}$ & $\begin{array}{l}65.5(58.1 \\
72.9)\end{array}$ & -1.3 & \\
\hline \multicolumn{10}{|c|}{ Year of report } \\
\hline 2011-2013 & 122 & 120 & 71 & 35 & $206(187,226)$ & $\begin{array}{l}59.3(52.6 \\
66.0)\end{array}$ & $\begin{array}{l}58.3(51.6 \\
65.1)\end{array}$ & 1.0 & \multirow[t]{2}{*}{$<}$. \\
\hline 2014-2015 & 90 & 82 & 66 & 6 & $112(106,118)$ & $\begin{array}{l}80.6(73.2 \\
87.9)\end{array}$ & $\begin{array}{l}73.4(65.2 \\
81.6)\end{array}$ & 7.2 & \\
\hline \multicolumn{10}{|l|}{$\begin{array}{l}\text { Size of } \\
\text { municipality }\end{array}$} \\
\hline $\begin{array}{l}<10,000 \\
\text { people }\end{array}$ & 27 & 28 & 22 & 2 & $35(32,37)$ & $\begin{array}{l}78.7(65.0 \\
92.4)\end{array}$ & $\begin{array}{l}81.6(68.7 \\
94.6)\end{array}$ & -2.9 & \multirow[t]{2}{*}{0.100} \\
\hline $\begin{array}{l}\geq 10,000 \\
\text { people }\end{array}$ & 177 & 148 & 110 & 23 & $238(225,252)$ & $\begin{array}{l}74.4(68.9 \\
80.0)\end{array}$ & $\begin{array}{l}62.2(56.1 \\
68.4)\end{array}$ & 12.2 & \\
\hline \multicolumn{10}{|l|}{$\begin{array}{l}\text { Country of } \\
\text { birth }\end{array}$} \\
\hline Spain & 194 & 188 & 127 & 32 & $287(271,304)$ & $\begin{array}{l}67.6(62.2 \\
73.0)\end{array}$ & $\begin{array}{l}65.5(60.0 \\
71.0)\end{array}$ & 2.1 & \multirow[t]{2}{*}{0.696} \\
\hline $\begin{array}{l}\text { Other } \\
\text { countries }\end{array}$ & 18 & 14 & 10 & 3 & $25(20,30)$ & $\begin{array}{l}72.3(54.7 \\
89.9)\end{array}$ & $\begin{array}{l}56.2(36.7 \\
75.7)\end{array}$ & 16.1 & \\
\hline \multicolumn{10}{|c|}{$\begin{array}{l}\text { Number of } \\
\text { hospital beds }\end{array}$} \\
\hline$<200$ & 60 & 65 & 40 & 13 & $97(87,108)$ & $\begin{array}{l}61.7(52.1 \\
71.4)\end{array}$ & $\begin{array}{l}66.9(57.5 \\
76.2)\end{array}$ & -5.1 & \multirow[t]{2}{*}{0.514} \\
\hline$\geq 200$ & 149 & 137 & 97 & 22 & $210(197,224)$ & $\begin{array}{l}70.9(64.7 \\
77.0)\end{array}$ & $\begin{array}{l}65.2(58.7 \\
71.6)\end{array}$ & 5.7 & \\
\hline \multicolumn{10}{|l|}{ Clinical form } \\
\hline Meningitis & 116 & 131 & 84 & 18 & $181(169,193)$ & $\begin{array}{l}64.2(57.2 \\
71.2)\end{array}$ & $\begin{array}{l}72.5(66.0 \\
79.0)\end{array}$ & -8.3 & \multirow[t]{2}{*}{0.936} \\
\hline Sepsis & 82 & 66 & 50 & 10 & $108(99,117)$ & $\begin{array}{l}75.9(67.9 \\
84.0)\end{array}$ & $\begin{array}{l}61.1(51.9 \\
70.3)\end{array}$ & 14.8 & \\
\hline \multicolumn{10}{|l|}{$\begin{array}{l}\text { Type of } \\
\text { reporting } \\
\text { centre }\end{array}$} \\
\hline Private & 21 & 1 & 1 & 0 & $21(21,21)$ & $\begin{array}{l}100(100 \\
100)\end{array}$ & $\begin{array}{l}4.8(-4.4 \\
13.9)\end{array}$ & 95.2 & \multirow[t]{2}{*}{0.002} \\
\hline Public & 190 & 201 & 136 & 26 & $281(267,295)$ & $\begin{array}{l}67.7(62.2 \\
73.2)\end{array}$ & $\begin{array}{l}71.6(66.4 \\
76.9)\end{array}$ & -3.9 & \\
\hline
\end{tabular}

There were no differences in sensitivity between in $<15$ years and $\geq 15$ years age groups $(P$-value $=0.468)$ in either source although it was higher in the $<15$ years $(69.1 \%$; 
$95 \% \mathrm{Cl} 62.6-75.7$ in the SDR and $66.5 \% ; 95 \% \mathrm{Cl} 59.8-73.2$ in the MR) S. The age groups with the highest sensitivity were $2-4$ years in the SDR, with $80.3 \%$ (95\% Cl 68.5-92.1), and 35-44 years in the MRS, with $80.5 \%(95 \% \mathrm{Cl} 60.4-100.0)$ (Fig. 1).

In 2011-2013, sensitivity for the SDR and the MRS were $59.3 \%(95 \% \mathrm{Cl} 52.6-66)$ and $58.3 \%(95 \% \mathrm{Cl} 51.6-65.1)$, respectively, lower than that in $2014-2015$ (80.6\%; 95\% Cl 73.2-87.9, for the SDR and 73.4\%; 95\% Cl 65.2-81.6, for the MRS $(\mathrm{P}<0.001)$ ) (Table 3). 2014 showed the highest sensitivity for both sources: 91.3\% (95\% Cl 83.2-99.4) for the SDR and 73.9\% (95\% Cl 61.2-86.6) for the MRS (Fig. 2). 2011 was the only year in which the MRS had a higher sensitivity than the SDR $(56.4 \% ; 95 \% \mathrm{Cl} 47.1-65.8$ and $39.8 \%$; $95 \% \mathrm{Cl} 30.6-49.0$, respectively). In private centres the sensitivity of the SDR was $100 \%$ (95\% Cl $100-100)$ and that of the MRS was $4.8 \%(95 \% \mathrm{Cl}-4.4-13.9)$. No differences were found in other characteristics analysed.

For I meningitis, 116 and 131 cases were reported by the SDR and the MRS, respectively. The estimated number of meningitis cases was 181 , and 18 cases were not reported by either source. The highest sensitivity was detected in the MRS (72.5\%; 95\% Cl 66-79) compared with the SDR (64.2\%; $95 \% \mathrm{Cl} 57.2-$

71.2) $(\mathrm{P}<0.001)$ (Table 4). 2014-2015 showed a higher sensitivity in both sources compared with $2011-2013: 82.4 \%(95 \% \mathrm{Cl} 72.7-92)$ in the MRS and $75.6 \%(95 \% \mathrm{Cl} 64.7-86.5)$ in the SDR. Public centres had a higher sensitivity in the MRS $(77.7 \%$; $95 \% \mathrm{Cl} 71.4-84.0)$ and in the SDR (63.9\%; $95 \% \mathrm{Cl} 56.6-71.2)$ $(\mathrm{P}<0.037)$. 
Table 4

Capture-recapture analysis of meningococcal meningitis reported to the SDR and MRS stratified by characteristics, Catalonia 2011-2015

\begin{tabular}{|c|c|c|c|c|c|c|c|c|c|}
\hline & $\begin{array}{l}\text { No. } \\
\text { records in } \\
\text { SDR }\end{array}$ & $\begin{array}{l}\text { No. } \\
\text { records in } \\
\text { MRS }\end{array}$ & $\begin{array}{l}\text { Matched } \\
\text { records }\end{array}$ & $\begin{array}{l}\text { Calculated } \\
\text { unreported } \\
\text { cases }\end{array}$ & $\begin{array}{l}\text { Estimated total } \\
\text { no. of cases } \\
(95 \% \mathrm{Cl})\end{array}$ & $\begin{array}{l}\text { Sensitivity } \\
\text { SDR (\%) } \\
(95 \% \mathrm{Cl})\end{array}$ & $\begin{array}{l}\text { Sensitivity } \\
\text { MRS (\%) } \\
(95 \% \mathrm{Cl})\end{array}$ & $\begin{array}{l}\text { Difference in } \\
\text { sensitivities (\%) }\end{array}$ & $\begin{array}{l}P \text { - } \\
\text { value }\end{array}$ \\
\hline All cases & 116 & 131 & 84 & 18 & $181(169,193)$ & $\begin{array}{l}64.2(57.2, \\
71.2)\end{array}$ & $\begin{array}{l}72.5(66.0 \\
79.0)\end{array}$ & -8.3 & $<.001$ \\
\hline \multicolumn{10}{|l|}{ Age group } \\
\hline$<15$ years & 72 & 81 & 51 & 13 & $115(104,125)$ & $\begin{array}{l}63.1(54.3, \\
72.0)\end{array}$ & $\begin{array}{l}71.0(62.7 \\
79.3)\end{array}$ & -7.9 & \multirow[t]{2}{*}{0.682} \\
\hline$\geq 15$ years & 43 & 49 & 32 & 6 & $66(60,73)$ & $\begin{array}{l}65.5(53.9 \\
77.0)\end{array}$ & $\begin{array}{l}74.6(64.1, \\
85.1)\end{array}$ & -9.1 & \\
\hline \multicolumn{10}{|l|}{ Sex } \\
\hline Male & 62 & 69 & 47 & 7 & $91(84,98)$ & $\begin{array}{l}68.2(58.6, \\
77.8)\end{array}$ & $\begin{array}{l}75.9(67.1, \\
84.7)\end{array}$ & -7.7 & \multirow[t]{2}{*}{0.245} \\
\hline Female & 54 & 62 & 37 & 12 & $91(81,101)$ & $\begin{array}{l}59.9(49.8 \\
70.0)\end{array}$ & $\begin{array}{l}68.7(59.2, \\
78.3)\end{array}$ & -8.9 & \\
\hline \multicolumn{10}{|l|}{ Year of report } \\
\hline 2011-2013 & 71 & 82 & 47 & 18 & $124(111,137)$ & $\begin{array}{l}57.5(48.8 \\
66.2)\end{array}$ & $\begin{array}{l}66.4(58.1 \\
74.7)\end{array}$ & -8.9 & \multirow[t]{2}{*}{0.013} \\
\hline 2014-2015 & 45 & 49 & 37 & 3 & $60(56,64)$ & $\begin{array}{l}75.6(64.7 \\
86.5)\end{array}$ & $\begin{array}{l}82.4(72.7 \\
92.0)\end{array}$ & -6.7 & \\
\hline \multicolumn{10}{|l|}{$\begin{array}{l}\text { Size of } \\
\text { municipality }\end{array}$} \\
\hline $\begin{array}{l}<10,000 \\
\text { people }\end{array}$ & 19 & 20 & 16 & 1 & $24(22,26)$ & $\begin{array}{l}80.2(64.1, \\
96.2)\end{array}$ & $\begin{array}{l}84.4(69.8, \\
99.0)\end{array}$ & -4.2 & \multirow[t]{2}{*}{0.165} \\
\hline $\begin{array}{l}\geq 10,000 \\
\text { people }\end{array}$ & 93 & 93 & 65 & 12 & $133(124,143)$ & $\begin{array}{l}70.0(62.2 \\
77.8)\end{array}$ & $\begin{array}{l}70.0(62.2 \\
77.8)\end{array}$ & 0.0 & \\
\hline \multicolumn{10}{|l|}{$\begin{array}{l}\text { Country of } \\
\text { birth }\end{array}$} \\
\hline Spain & 107 & 120 & 77 & 17 & $167(155,179)$ & $\begin{array}{l}64.3(57.0 \\
71.5)\end{array}$ & $\begin{array}{l}72.1(65.3 \\
78.9)\end{array}$ & -7.8 & \multirow[t]{2}{*}{0.862} \\
\hline $\begin{array}{l}\text { Other } \\
\text { countries }\end{array}$ & 9 & 11 & 7 & 1 & $14(12,17)$ & $\begin{array}{l}64.3(39.2, \\
89.4)\end{array}$ & $\begin{array}{l}78.6(57.1 \\
100.0)\end{array}$ & -14.3 & \\
\hline \multicolumn{10}{|c|}{$\begin{array}{l}\text { Number of } \\
\text { hospital beds }\end{array}$} \\
\hline$<200$ & 31 & 40 & 23 & 6 & $54(47,61)$ & $\begin{array}{l}57.7(44.5 \\
70.9)\end{array}$ & $\begin{array}{l}74.5(62.8 \\
86.2)\end{array}$ & -16.8 & \multirow[t]{2}{*}{0.516} \\
\hline$\geq 200$ & 84 & 91 & 61 & 11 & $126(116,135)$ & $\begin{array}{l}67.1(58.9 \\
75.4)\end{array}$ & $\begin{array}{l}72.7(64.9 \\
80.5)\end{array}$ & -5.6 & \\
\hline \multicolumn{10}{|l|}{$\begin{array}{l}\text { Type of } \\
\text { reporting } \\
\text { centre }\end{array}$} \\
\hline Private & 9 & 1 & 1 & 0 & $9(9,9)$ & $\begin{array}{l}100.0 \\
(100.0 \\
100.0)\end{array}$ & $\begin{array}{l}11.1(-9.4 \\
31.6)\end{array}$ & 88.9 & \multirow[t]{2}{*}{0.037} \\
\hline Public & 107 & 130 & 83 & 14 & $168(158,178)$ & $\begin{array}{l}63.9(56.6, \\
71.2)\end{array}$ & $\begin{array}{l}77.7(71.4, \\
84.0)\end{array}$ & -13.7 & \\
\hline
\end{tabular}

For sepsis, 82 cases and 66 cases were reported by the SDR and the MRS, respectively. The sensitivity was higher for the SDR (75.9\%; $95 \% \mathrm{CI} 67.9-84)$ than the MRS (61.1\%; 95\% Cl 51.9-70.3) (Table 5). There were 108 estimated cases and 10 cases were not reported by either source. The sensitivity was higher in the $<15$ years than in the $\geq 15$ years in both sources, but higher in the SDR $(81.1 \% ; 95 \% \mathrm{Cl} 71.1-91.1$ versus $71 \% ; 95 \% \mathrm{Cl} 59.4-82.5$ for the $\mathrm{MRS}$; $\mathrm{P}=0.0036)$, and higher in 2014-2015 than in 2011-2013 (87.6\%; 95\%Cl 78-97.3 for the SDR and 71.9\%; 95\% Cl 58.7-85.1 for the MRS) (P<0.015). 
Table 5

Capture-recapture analysis of meningococcal septicaemia reported to the SDR and MRS stratified by characteristics, Catalonia 2011-2015

\begin{tabular}{|c|c|c|c|c|c|c|c|c|c|}
\hline & $\begin{array}{l}\text { No. } \\
\text { records in } \\
\text { SDR }\end{array}$ & $\begin{array}{l}\text { No. } \\
\text { records in } \\
\text { MRS }\end{array}$ & $\begin{array}{l}\text { Matched } \\
\text { records }\end{array}$ & $\begin{array}{l}\text { Calculated } \\
\text { unreported } \\
\text { cases }\end{array}$ & $\begin{array}{l}\text { Estimated total } \\
\text { no. of cases } \\
(95 \% \mathrm{Cl})\end{array}$ & $\begin{array}{l}\text { Sensitivity } \\
\text { SDR (\%) } \\
(95 \% \mathrm{Cl})\end{array}$ & $\begin{array}{l}\text { Sensitivity } \\
\text { MRS (\%) } \\
(95 \% \mathrm{Cl})\end{array}$ & $\begin{array}{l}\text { Difference in } \\
\text { sensitivities } \\
(\%)\end{array}$ & $\begin{array}{l}P \text { - } \\
\text { value }\end{array}$ \\
\hline All cases & 82 & 66 & 50 & 10 & $108(99,117)$ & $\begin{array}{l}75.9(67.9 \\
84.0)\end{array}$ & $\begin{array}{l}61.1(51.9, \\
70.3)\end{array}$ & 14.8 & $\begin{array}{l}< \\
0.001\end{array}$ \\
\hline \multicolumn{10}{|l|}{$\begin{array}{l}\text { Age at } \\
\text { notification, } \\
\text { years }\end{array}$} \\
\hline$<15$ years & 48 & 42 & 34 & 4 & $60(55,64)$ & $\begin{array}{l}\text { 81.1 (71.1, } \\
91.1)\end{array}$ & $\begin{array}{l}71.0(59.4, \\
82.5)\end{array}$ & 10.1 & \multirow[t]{2}{*}{0.036} \\
\hline$\geq 15$ years & 34 & 23 & 16 & 8 & $49(40,58)$ & $\begin{array}{l}70.3(57.4, \\
83.1)\end{array}$ & $\begin{array}{l}47.5(33.4, \\
61.6)\end{array}$ & 22.7 & \\
\hline \multicolumn{10}{|l|}{ Sex } \\
\hline Male & 43 & 27 & 22 & 5 & $53(47,59)$ & $\begin{array}{l}81.8(71.3, \\
92.2)\end{array}$ & $\begin{array}{l}51.3(37.8, \\
64.8)\end{array}$ & 30.4 & \multirow[t]{2}{*}{0.315} \\
\hline Female & 39 & 39 & 28 & 5 & $55(49,60)$ & $\begin{array}{l}72.0(60.0 \\
83.9)\end{array}$ & $\begin{array}{l}72.0(60.0 \\
83.9)\end{array}$ & 0.0 & \\
\hline \multicolumn{10}{|c|}{ Year of report } \\
\hline 2011-2013 & 43 & 34 & 22 & 11 & $66(56,77)$ & $\begin{array}{l}65.2(53.6 \\
76.7)\end{array}$ & $\begin{array}{l}51.5(39.5, \\
63.6)\end{array}$ & 13.6 & \multirow[t]{2}{*}{0.015} \\
\hline 2014-2015 & 39 & 32 & 28 & 2 & $45(42,48)$ & $\begin{array}{l}87.6(78.0 \\
97.3)\end{array}$ & $\begin{array}{l}71.9(58.7, \\
85.1)\end{array}$ & 15.7 & \\
\hline \multicolumn{10}{|l|}{$\begin{array}{l}\text { Size of } \\
\text { municipality }\end{array}$} \\
\hline $\begin{array}{l}<10,000 \\
\text { people }\end{array}$ & 7 & 7 & 5 & 1 & $10(8,12)$ & $\begin{array}{l}72.2(44.0 \\
100.0)\end{array}$ & $\begin{array}{l}72.2(44.0 \\
100.0)\end{array}$ & 0.0 & \multirow[t]{2}{*}{0.918} \\
\hline $\begin{array}{l}\geq 10,000 \\
\text { people }\end{array}$ & 71 & 52 & 43 & 6 & $86(80,93)$ & $\begin{array}{l}82.9(74.9 \\
90.8)\end{array}$ & $\begin{array}{l}60.7(50.3, \\
71.0)\end{array}$ & 22.2 & \\
\hline \multicolumn{10}{|l|}{$\begin{array}{l}\text { Country of } \\
\text { birth }\end{array}$} \\
\hline Spain & 73 & 63 & 47 & 9 & $98(90,106)$ & $\begin{array}{l}74.7(66.1, \\
83.3)\end{array}$ & $\begin{array}{l}64.5(55.0 \\
74.0)\end{array}$ & 10.2 & \multirow[t]{2}{*}{0.275} \\
\hline $\begin{array}{l}\text { Other } \\
\text { countries }\end{array}$ & 9 & 3 & 3 & 0 & $9(9,9)$ & $\begin{array}{l}100.0 \\
(100.0 \\
100.0)\end{array}$ & $\begin{array}{l}33.3(2.5 \\
64.1)\end{array}$ & 66.7 & \\
\hline \multicolumn{10}{|c|}{$\begin{array}{l}\text { Number of } \\
\text { hospital beds }\end{array}$} \\
\hline$<200$ & 25 & 23 & 16 & 4 & $36(31,42)$ & $\begin{array}{l}70.0(55.0 \\
85.1)\end{array}$ & $\begin{array}{l}\text { 64.4 (48.7, } \\
80.1)\end{array}$ & 5.6 & \multirow[t]{2}{*}{0.831} \\
\hline$\geq 200$ & 56 & 43 & 34 & 6 & $71(65,78)$ & $\begin{array}{l}79.2(69.7 \\
88.7)\end{array}$ & $\begin{array}{l}60.8(49.4 \\
72.2)\end{array}$ & 18.4 & \\
\hline \multicolumn{10}{|l|}{$\begin{array}{l}\text { Type of } \\
\text { reporting } \\
\text { centre }\end{array}$} \\
\hline Private & 9 & 0 & 0 & 0 & $9(9,9)$ & $\begin{array}{l}100.0 \\
(100.0 \\
100.0)\end{array}$ & $0(0.0,0.0)$ & 100 & \multirow[t]{2}{*}{0.988} \\
\hline Public & 73 & 66 & 50 & 8 & $97(89,104)$ & $\begin{array}{l}75.9(67.3 \\
84.4)\end{array}$ & $\begin{array}{l}\text { 68.6(59.3, } \\
77.9)\end{array}$ & 7.3 & \\
\hline
\end{tabular}

Serogroup B (Supplementary Table 1) showed the sensitivity of the SDR was higher than that of the MRS $(74.6 \%$; $95 \% \mathrm{Cl} 68.8-80.3$ and $69.6 \%$; $95 \% \mathrm{Cl} 63.5-$ 75.6, respectively). There were differences according to the period and the type of centre. In 2014-2015, the sensitivity was $87.1 \%(95 \% \mathrm{Cl} 79.7-94.5)$ for the SDR and $78.3 \%(95 \% \mathrm{Cl} 69.2-87.4)$ for the MRS $(P<0.002)$. In private centres, the sensitivity in SDR was $100 \%$ compared with $7.1 \%(95 \% \mathrm{Cl}-6.4-20.6)(P=$ $0.004)$ in MRS. The sensitivity was higher for IMD serogroup C cases in SDR than in MRS $(76.7 \%$; $95 \% \mathrm{Cl} 62.5-90.9$ and $62 \%$; $95 \% \mathrm{Cl} 45.6-78.3$, respectively) (Supplementary Table 2). 
All 22 deaths were reported in the SDR (CFR: 10.4\%), and the sensitivity of the SDR was higher than that of the $\mathrm{MRS}$ (100\%; $95 \mathrm{Cl} \% 100-100$ vs $50 \%$; $95 \% \mathrm{Cl}$ 29.1-70.9, $\mathrm{P}=0.104$ ) (Supplementary Table 3).

The results of the multinomial logit model for all cases are shown in Table 6 . The variables considered significant in defining the sensitivity of the two sources were year of report (2011-2013 versus 2014-2015) and size of municipality. With these variables in the model, the adjusted estimate of the total number of cases was 279 cases $(95 \% \mathrm{Cl} 266-296)$ and the estimated incidence rate was $0.7 / 100,000$ persons-year.

Table 6

Variables defining the sensitivity of the SDR and MRS in detecting invasive meningococcal diseases cases. Multinomial logit model

\begin{tabular}{|lll|}
\hline & OR $(95 \% \mathrm{Cl})$ & p-value \\
\hline Year of report (2014-2015) & $2.29(1.35,3.89)$ & 0.002 \\
\hline Size of municipality $(\geq 10,000$ people) & $0.51(0.23,1.12)$ & 0.093 \\
\hline OR: odds ratio; $n$ estimate: $279(266,296)$ & \\
\hline
\end{tabular}

\section{Discussion}

The sensitivity obtained by combining the two surveillance system for IMD cases was $88.5 \%$, greater than for each source s (67.9\% and $64.7 \%$, respectively). Globally, the SDR showed higher sensitivity than the MDR, mainly for cases of sepsis, I serogroup B and serogroup C, although for meningitis the sensitivity of the MDR was higher than that of the SDR.

Similar studies found greater sensitivities by combining data systems than we did. Baldovin et al. [23] in Italy, reported an overall sensitivity of $94.7 \%$ by combining four data sources (mandatory notification system, laboratory surveillance, invasive bacterial surveillance and hospital discharge). Jansson et al. [24], in Sweden, found a global sensitivity of $98.7 \%, 91.1 \%$ for clinical notification and $85.4 \%$ for laboratory reporting. In Austria a good agreement between the National Reference Center for meningococci and the hospital discharge was found, although a clinical review of hospital discharge data was necessary to detect false positive cases recorded. [25]

The sensitivity was similar in children aged $<15$ years than in persons aged $\geq 15$ years in both sources $(69.1 \%$ for the SDR and $66.5 \%$ for the MRS; $P=$ 0.468). Gibson et al., [26] in Australia, analysed IMD sensitivity in children aged < 15 years in three sources: notifiable system, hospitalized patients and mortality data. They found a greater sensitivity (99.5\%) than we did, although $15 \%$ of hospitalized children were false-positive cases.

We found a greater sensitivity for meningitis in the MRS than in the SDR ( $72.5 \%$ vs $64.2 \%)$. A possible explanation is that meningitis is considered a more serious disease and, therefore, microbiologists are more sensitive to its reporting. It is difficult to compare our results with those of other studies, since other sources of information were used or the independence of data sources was presumed but not demonstrated, [25] which is essential when using the capturerecapture method.

Notification of confirmed cases of IMD by laboratories is essential in epidemiological surveillance. [27] Molecular information on circulating serogroups that is required to implement public health measures such as vaccination is essential to control the disease [28] and evaluate the impact of available vaccines.

In the absence of automated electronic reporting, monitoring and increasing the speed of laboratory reports may allow the public health department to administer chemoprophylaxis and vaccination to contacts. [28] Although a higher sensitivity has been reported for electronic reporting than for paper-based reports by some authors, [29] during the study period, electronic surveillance was used in the SDR but not in the MDR, which may explain, at least in part, why the MDR had a lower sensitivity than the SDR. [30]

In the multinomial model, the 2014-2015 period and the size of the municipality show a higher sensitivity in the SDR, suggesting that IMD was well recorded in the two surveillance systems, although 36 cases (11.5\%) were not captured by either source. This suggests there was underreporting, despite the clinical severity of the disease. It is very important to improve reporting by all physicians and microbiologists to the SDR and MDR to assess the impact of interventions such as immunization.

The estimated IMD incidence rate of $0.7 / 100,000$ persons-year found in the multinomial model is less than that found using capture-recapture (0.83/100,000 persons-year) but higher than that calculated using the SDR $(0.56 / 100,000$ persons-year) or MDR data (0.54/100,000 persons-year). Other European studies showed incidence rates of between 0.39 [23] and 1.18/100,000 persons-year. [25]

The sensitivity of the two sources were intermediate ( $67.9 \%$ for the SDR and $64.7 \%$ for the MRS). The lower sensitivity of the MRS may be due to the fact that the MRS is a sentinel system with a coverage of $82 \%$ of acute hospital beds and without private centres. In our series, 21 cases (10\%) included in the SDR were reported by private centres, while only one case $(0.5 \%)$ was reported to the MSR; this patient was finally transferred to a public hospital. The inclusion of cases that have an equal probability of selection in one source might lead to an overestimation. Other authors have reported this limitation when the hospital discharge data set includes probable cases which are not included in the reference centre. [25]

Death was registered in 22 cases (10.5\%), similar to that reported in other European countries (ECDC) but slightly lower than that observed in Italy (14\%) using the capture-recapture method. [23] All cases were reported to the SDR but only $50 \%$ were reported to the MRS, indicating that clinical data are better in 
the SDR than in the MRS. Other authors have used mortality data for capture-recapture analysis and concluded that all deaths were reported in notifiable systems. [26]

The sensitivity of the sources studied for the surveillance of IMD cannot be generalized to other diseases because physicians' or microbiologists' perception of the importance of IMD differs from that of other diseases. [29]

The main strength of this study is that the two sources had wide coverage. The SDR is a universal epidemiological surveillance source and, unlike the MDR, is a sentinel source, with a high coverage of $83 \%$. Cases with PIC accounted for $85.5 \%$ of all cases reported to detect whether cases were coincident or not. In addition, the independence of the two sources was demonstrated, complying with the premise of the capture-recapture method.

A limitation of the study was that not all cases had the same probability of being selected from a given source. Cases diagnosed in private centres or public centres that did not participate in the MRS could not be reported by this system and this may explain, at least in part, the lower sensitivity than the SDR. This highlights the importance of including public and private centres to increase the robustness of the MRS. Another limitation was that we did not analyse the role of the electronic surveillance system, although a previous study detected greater sensitivity of the SDR when electronic surveillance was introduced. [30]

\section{Conclusions}

The sensitivity of enhanced surveillance through the combination of two complementary sources (statutory reporting by physicians and microbiological reporting by microbiologists) was higher than that of the individual sources. These systems are complementary and constitute the basic sources of information necessary for adequate epidemiological surveillance of IMD. Specific studies to estimate the factors associated with under-reporting are needed to reinforce epidemiological surveillance of this disease.

\section{Declarations}

\section{Ethics approval and consent to participate}

Not applicable

\section{Consent of publication}

Not applicable

\section{Availability of data and materials}

The datasets used and analysed during the current study available from the corresponding author on reasonable request.

\section{Competing interests}

The authors declare that they have no competing interests.

\section{Funding}

This work was supported partially by CIBER of Epidemiology and Public Health (CIBERESP), Carlos III Health Institute and the Catalan Agency for the Management of Grants for University Research [AGAUR Grant Number 2017 / SGR 1342]. The funding sources played no part in the design of the study and collection, analysis, and interpretation of data and in writing the manuscript.

\section{Author's contributions}

PC analyzed and interpreted data, studied conception and design of the study and writes the manuscript; MV and NS did statistical analysis; GC revised and collected data; TG,SH,LR collected data; MJ revised the study and AD did critical revision and got funding.

\section{Acknowledgements}

\section{The Working Group of the Microbiological Reporting System of Catalonia is composed by:}

M. Teresa Bastida (Fundació Hospital Esperit Sant); Frederic Ballester; Isabel Pujol (Hospital Universitari de Sant Joan de Reus); Miguel Ángel Benítez, Alba Cebollero (Consorci de Laboratoris Intercomarcal de l'Alt Penedès); Jordi Vila, Jordi Bosch, (Hospital Clínic); Ana Calderón (Hospital Municipal de Badalona); Margarida Curriu (Hospital Comarcal de Sant Bernabé); M. Ángeles Domínguez, Fe Tubau Quintano (Hospital Universitari de Bellvitge); Jose Manuel Ramírez (Hospital Universitari de Girona Dr. Josep Trueta); Ma José Fusté (Clínica de Terres de l’Ebre); Carme Gallés, Pilar Hernández Pérez, Elisenda Capdevila Gil de Bernabé Corporació de Salut del Maresme i La Selva); Paula Gassiot (Hospital de Figueres); Frederic Gómez (Hospital Universitari de Tarragona Joan XXIII); Araceli González-Cuevas (Hospital General del Parc Sanitari Sant Joan de Déu); Marius Juanpere (Hospital Móra d’Ebre); Carmen Muñoz-Almagro, Amaresh Pérez-Argüello (Hospital Sant Joan de Déu. Esplugues de Llobregat); Carmina Martí (Hospital General de Granollers); Núria Margall (Hospital de la Santa Creu i Sant Pau); Lurdes Matas, Montserrat Gimenez (Hospital Universitari Germans Trias i Pujol); Montserrat Morta, Glòria Trujillo (Hospital Sant Joan de Déu. Manresa-Fundació Althaia); Sílvia Noguer (Hospital del Vendrell); Montserrat Olsina (Hospital General de Catalunya); Amaia Oteiza (H. Palamós); Pepa Pérez (Catlab-Centre Analítiques Terrassa); Mar Olga Pérez-Moreno (Hospital Verge de la Cinta de Tortosa); Tomás Pumarola, Juanjo González (Hospital Universitari Vall d’Hebron); Xavier Raga (Hospital de Sant Pau i Santa Tecla); Mercè Garcia, Mercè Ribelles (Hospital Universitari Arnau de Vilanova de 
Lleida); Esther Sanfeliu (Hospital d’Olot Comarcal de la Garrotxa); Goretti Sauca (Hospital de Mataró); Dionisia Fontanals, Isabel Sanfeliu (Corporació Sanitaria Parc Taulí, Sabadell) i Anna Vilamala (Hospital General de Vic).

\section{The Working Group of the Epidemiological Surveillance Network of Catalonia is composed by:}

César Arias, Irene Barrabeig, Neus Camps, Mònica Carol, Núria Follia, Pere Godoy, Ana Martínez, Sofia Minguell, Ignasi Parron, Mª Rosa Sala-Farré, Ariadna Rovira (Agència de Salut Pública de Catalunya), Cristina Rius (Agència de Salut Pública de Barcelona).

Working Group of the Microbiological Reporting System of Catalonia and Working Group of the Epidemiological Surveillance Network of Catalonia

Maria Teresa Bastida

Laboratori de Microbiologia

Fundació Hospital Esperit Sant

C/ Pons i Rabadà s/n

08923 Santa Coloma de Gramenet, Spain

Frederic Ballester

Laboratori de Referencia Sud

Hospital Sant Joan de Reus

Av. Dr Josep Laporte, 2,

43204 Reus, Tarragona, Spain

Isabel Pujol

Laboratori de Referencia Sud

Hospital Sant Joan de Reus

Av. Dr Josep Laporte, 2,

43204 Reus, Tarragona, Spain

Miguel Angel Benítez

Servei de Microbiologia

CLILAB Diagnòstics

C/ Espirall, s/n

08720 Vilafranca del Penedès, Barcelona, Spain

Alba Cebollero

Servei de Microbiologia

CLILAB Diagnòstics

C/ Espirall, s/n

08720 Vilafranca del Penedès, Barcelona, Spain 
Servei de Microbiologia

Hospital Clínic de Barcelona

C/ Villarroel, 170

08036 Barcelona, Spain.

Jordi Bosch

Servei de Microbiologia

Hospital Clínic de Barcelona

C/ Villarroel, 170

08036 Barcelona, Spain.

Ana Calderon

Servei de Microbiologia

Hospital Municipal de Badalona

C/ Via Augusta, 9-13

08911 Badalona, Barcelona, Spain

Margarida Curriu

Servei de Microbiologia

Hospital Sant Bernabé

Ctra. de Ribes, s/n

08600 Berga, Spain

M Angeles Dominguez

Hospital Universitari de Bellvitge, Universitat de Barcelona,

C/ Feixa Llarga s/n

08907 L'Hospitalet, Barcelona, Spain

Fe Tubau Quintano

Hospital Universitari de Bellvitge, Universitat de Barcelona,

C/ Feixa Llarga s/n

08907 L’Hospitalet, Barcelona, Spain

Jose Manuel Ramirez

Àrea de Microbiologia, Laboratori Clínic - Institut Català de la Salut Girona

Hospital Universitari Dr. Josep Trueta

Page $13 / 23$ 
Av. França, s/n

17007 Girona, Spain

$M^{a}$ Jose Fusté

Servei de Microbiologia

Clínica Terres de l'Ebre

PI. De Joaquim Bau, 6-8

43500 Tortosa, Tarragona, Spain

Carme Gallés

Unitat de Microbiologia, Servei d'Anàlisis Clíniques

Corporació de Salut del Maresme i la Selva

C/ Sant Jaume, 209-217

08370 Calella, Barcelona, Spain

Pilar Hernandez Pérez

Unitat de Microbiologia, Servei d'Anàlisis Clíniques

Corporació de Salut del Maresme i la Selva.

C/ Sant Jaume, 209-217

08370 Calella, Barcelona, Spain

Elisenda Capdevila Gil de Bernabe

Unitat de Microbiologia, Servei d'Anàlisis Clíniques

Corporació de Salut del Maresme i la Selva.

C/ Sant Jaume, 209-217

08370 Calella, Barcelona, Spain

Paula Gassiot

Àrea de Microbiologia, Laboratori d'Anàlisis Clíniques

Hospital de Figueres

Rda. Rector Arolas, s/n

17600 Figueres, Girona, Spain

Frederic Gómez-Bertomeu

Àrea de Microbiologia, Laboratori Clínic ICS - Camp de Tarragona

Hospital Joan XXIII

Page $14 / 23$ 
C/ Dr. Mallafrè Guasch, 4

43005 Tarragona, Spain

Araceli González-Cuevas

Laboratori de Microbiologia

Hospital General del Parc Sanitari Sant Joan de Déu

Camí Vell de la Colònia, 25

08830 Sant Boi de Llobregat, Barcelona, Spain

Marius Juanpere

Servei de Microbiologia

Hospital Comarcal Móra d’Ebre

$\mathrm{C} /$ de Benet Messeguer, $\mathrm{s} / \mathrm{h}$

43770 Móra d'Ebre, Tarragona, Spain

Carmen Muñoz-Almagro

Hospital Universitari Sant Joan de Déu

Pg. Sant Joan de Déu 2

08950 Esplugues, Barcelona, Spain

Amaresch Perez Arguello

Hospital Universitari Sant Joan de Déu

Pg. Sant Joan de Déu 2

08950 Esplugues, Barcelona, Spain

Carmina Martí

Laboratori de Microbiologia

Hospital General de Granollers

Av. Francesc Ribas, s/n

08402 Granollers, Barcelona, Spain

Nuria Margall

Servei de Microbiologia

Hospital Santa Creu i Sant Pau

C/ de Sant Quintí, 89 
08041 Barcelona, Spain

Lurdes Matas

Laboratori clínic Metropolitana Nord

Hospital Universitari Germans Trias i Pujol

Ctra. de Canyet, s/n

08916 Badalona, Barcelona, Spain

Montserrat Giménez

Laboratori clínic Metropolitana Nord

Hospital Universitari Germans Trias i Pujol

Ctra. de Canyet, s/n

08916 Badalona, Barcelona, Spain

Montserrat Morta

Servei de Microbiologia

Hospital Sant Joan de Déu. Fundació ALTHAIA

C/ Dr. Joan Soler, s/n

08243 Manresa, Barcelona, Spain

Gloria Trujillo

Servei de Microbiologia

Hospital Sant Joan de Déu. Fundació ALTHAIA

C/ Dr. Joan Soler, s/n

08243 Manresa, Barcelona, Spain

Silvia Noguer

Hospital del vendrell

Ctra. Barcelona, s/n,

43700 El Vendrell, Tarragona, Spain

Montserrat Olsina

Laboratori d'Anàlisis Clínics, Microbiologia

Hospital General de Catalunya

C/ Pedro i Pons, 1

08190 Sant Cugat del Vallès, Barcelona, Spain 
Amaia Oteiza Ubanell

Laboratori d'Anàlisis Clíniques

Hospital de Palamós

C/ Hospital, 36,

17230 Palamós, Spain

Pepa Perez

Departament de Microbiologia, Catlab - Centre Analítiques Terrassa, AIE

Parc Logístic de Salut

Vial Sant Jordi, s/n

08232 Viladecavalls, Barcelona, Spain

Mar Olga Pérez-Moreno

Àrea de Microbiologia, Laboratori Clínic ICS - Terres de l'Ebre

Hospital Verge de la Cinta

C/ de les Esplanetes, 14

43500 Tortosa, Tarragona, Spain

Tomas Pumarola

Servei de Microbiologia

Hospital Universitari Vall d'Hebron

Pg. De la Vall d'Hebron, 119-129

08035 Barcelona, Spain

Juanjo Gonzales

Servei de Microbiologia

Hospital Universitari Vall d'Hebron

Pg. De la Vall d'Hebron, 119-129

08035 Barcelona, Spain

Xavier Raga

Laboratori de Microbiologia

Hospital Sant Pau i Santa Tecla

Rambla Vella, 14

43003 Tarragona, Spain 
Mercè Garcia

Secció Microbiologia, Servei d'Anàlisis Clíniques

Hospital Universitari Arnau de Vilanova de Lleida

Av. Rovira Roure, 80

25198 Lleida, Barcelona, Spain

Mercè Ribelles

Secció Microbiologia, Servei d'Anàlisis Clíniques

Hospital Universitari Arnau de Vilanova de Lleida

Av. Rovira Roure, 80

25198 Lleida, Barcelona, Spain

Esther Sanfeliu

Servei d’Anàlisis Clíniques, Secció de Microbiologia

Hospital d'Olot Comarcal de la Garrotxa

Av. dels Països Catalans, 86

17800 Olot, Girona, Spain

Goretti Sauca

Servei d'Análisis clíniques, secció de Microbiologia

Hospital de Mataró

Ctra. de Cirera, 230

08304 Mataró, Barcelona, Spain

Dionisia Fontanals

Secció de Microbiologia

Parc Taulí Hospital Universitari, Institut d'Investigació i Innovació Parc Taulí I3PT, UAB

C/ Parc del Taulí, 1

08208 Sabadell, Barcelona, Spain

Isabel Sanfeliu

Secció de Microbiologia

Parc Taulí Hospital Universitari, Institut d’Investigació i Innovació Parc Taulí I3PT, UAB

C/ Parc del Taulí, 1

08208 Sabadell, Barcelona, Spain

Anna Vilamala

Page $18 / 23$ 
Servei de Microbiologia

Consorci Hospitalari de Vic

C/ Francesc Pla 'El Vigatà', 1

08500 Vic, Barcelona, Spain

The Working Group of the Epidemiological Surveillance Network of Catalonia is composed by:

César Arias

Servei de Vigilància Epidemiològica i Resposta a Emergències de Salut Pública al Vallès Occidental i Vallès Oriental

Carretera de Vallvidrera, 38 (CAP Turó de Can Mates)

08173 Sant Cugat del Vallès, Spain

Irene Barrabeig

Servei de Vigilància Epidemiològica i Resposta a Emergències de Salut Pública a Barcelona Sud

Carrer de la Feixa Llarga, s/n, Antiga Escola d'Infermeria, 3a. planta (Hospital Universitari de Bellvitge)

08907 L'Hospitalet de Llobregat, Spain

Neus Camps

Servei de Vigilància Epidemiològica i Resposta a Emergències de Salut Pública a Girona

Plaça de Pompeu Fabra, 1

17002 Girona, Spain

Mònica Carol

Servei de Vigilància Epidemiològica i Resposta a Emergències de Salut Pública a la Catalunya Central

Carrer Muralla de Sant Francesc, 49 4a planta - Edifici Pere III

08241 Manresa, Spain

Núria Follia

Servei de Vigilància Epidemiològica i Resposta a Emergències de Salut Pública a Girona

Plaça de Pompeu Fabra, 1

17002 Girona, Spain

Pere Godoy

Servei de Vigilància Epidemiològica i Resposta a Emergències de Salut Pública a Lleida i Alt Pirineu i Aran

Avinguda de l'Alcalde Rovira Roure, 2

25006 Lleida, Spain

Page $19 / 23$ 
Ana Martínez

Sub-direcció General de Vigilància i Resposta a Emergències de Salut Pública

Agència de Salut Pública de Catalunya, Generalitat de Catalunya

C/ Roc Boronat, 81-95

08005 Barcelona, Spain

Sofia Minguell

Servei de Vigilància Epidemiològica i Resposta a Emergències de Salut Pública al Camp de Tarragona i Terres de l'Ebre

Avinguda de la Reina Maria Cristina, 54

43002 Tarragona, Spain

Ignasi Parron

Servei de Vigilància Epidemiològica i Resposta a Emergències de Salut Pública al Barcelonès Nord i Maresme

C/ Roc Boronat, 81-95

08005 Barcelona, Spain

$M^{a}$ Rosa Sala-Farré

Servei de Vigilància Epidemiològica i Resposta a Emergències de Salut Pública al Vallès Occidental i Vallès Oriental

Carretera de Vallvidrera, 38 (CAP Turó de Can Mates)

08173 Sant Cugat del Vallès, Spain

Ariadna Rovira

Servei de Vigilància Epidemiològica i Resposta a Emergències de Salut Pública a Barcelona Sud

Carrer de la Feixa Llarga, s/n, Antiga Escola d'Infermeria, 3a. planta (Hospital Universitari de Bellvitge)

08907 L'Hospitalet de Llobregat, Spain

Cristina Rius

Agència de Salut Pública de Barcelona

Plaça de Lesseps, 1

08023 Barcelona, Spain

\section{References}

1. World Health Organization. Laboratory methods for the diagnosis of meningitis caused by Neisseria meningitidis, Streptococcus pneumoniae, and Haemophilus influenzae: WHO manual, 2nd ed. Geneve: WHO, 2011.

2. 2 European Centre for Disease Prevention and Control. Invasive meningococcal disease. In: ECDC. Annual epidemiological report for 2017. Stockholm: ECDC, 2019. https://www.ecdc.europa.eu/sites/default/files/documents/AER_for_2017-invasive-meningococcal-disease.pdf (Last accessed 27 January 2021)

3. Diez Izquierdo L, Martínez Sánchez EV, Amillategui dos Santos R, Cano Portero R. Enfermedad meningocócica en España. Análisis de la temporada 2016-2017. Bol Epidemiol Sem 2018;26:59-68. http://revista.isciii.es/index.php/bes/article/view/1063/1314.

Page 20/23 
4. Centers for Disease Control and Prevention (CDC). Epidemiology and prevention of vaccine-preventable diseases. Washington DC: Public Health Foundation, 2015.

5. Edmond K, Clark A, Korczak VS, Sanderson C, Griffiths UK, Rudan I. Global and regional risk of disabling sequelae from bacterial meningitis: a systematic review and meta-analysis. Lancet Infect Dis 2010;10:317-28.

6. CDC Guidelines Working Group. Updated guidelines for evaluating public health surveillance systems. Morb Mortal Wkly Rep 2001;50:1-35.

7. WHO. Protocol for the evaluation of epidemiological surveillance systems. https://apps.who.int/iris/handle/10665/63639 (Last accessed 6 September 2020).

8. Romaguera RA, German RR, Klaucke DN. Evaluating public health surveillance. In: Teutsch SM, Churchill RE, eds. Principles and practice of public health surveillance. New York: Oxford University Press, 2000: 176-193

9. Generalitat de Catalunya. Decret 2013/2015, de 15 de setembre, pel qual es crea la Xarxa de Vigilància Epidemiològica i es regulen els sistemes de notificació de malalties de declaració obligatòria i els brots epidèmics. DOGC 2015;6958:1-19.

10. Laska EM. The use of capture-recapture methods in public health. Bull World Health Organ 2002;80:845.

11. Freixa Blanxart M, Guàrdia Olmos J, Honrubia Serrano ML, Peró Cebollero. Validation of the capture - recapture method. Psichotema 2000;12(Suppl 2):231-5.

12. Statistical Institute of Catalonia. Statistical Institute of Catalonia. 2015. https://www.idescat.cat (Last accessed 18 January 2019)

13. Generalitat de Catalunya. Manual de notificació per als declarants al sistema de notificació de malalties de declaració obligatòria (MDO). 2016. https://canalsalut.gencat.cat/web/.content/_Professionals/Vigilancia_epidemiologica/documents/arxius/MANUAL_MDO_2016.pdf (Last accessed 27 January 2021).

14. Generalitat de Catalunya. Manual de procediment de notificació microbiològica obligatòria (SNMC). 2016. https://canalsalut.gencat.cat/web/.content/_Professionals/Vigilancia_epidemiologica/documents/arxius/manual_procediment.pdf (last accessed 27 January 2021).

15. Ciruela P, Izquierdo C, Broner S et al. Epidemiology of invasive pneumococcal disease in Catalonia Report 2012-2016. Generalitat de Catalunya 2018. https://canalsalut.gencat.cat/web/.content/_Professionals/Vigilancia_epidemiologica/documents/arxius/invasive_pneumococcal_2012_2016_ang.pdf (Last accessed 27 January 2021).

16. Chapman DG. Some properties of the hypergeometric distribution with applications to zoological sample censuses. Berkeley: University of California Press, 1951.

17. Ballivet S, Salmi LR, Dubourdieu D. Capture-recapture method to determine the best design of surveillance system. Application to a thyroid cancer registry. Eur J Epidemiol 2000;16:147-53.

18. Tilling K, Sterne JAC, Wolfe CDA. Estimation of the incidence of stroke using a capture-recapture model including covariates. Int $\mathrm{J}$ Epidemiol 2001;30:1351-9.

19. Alho JM. Logistic regression in capture-recapture models. Biometrics 1999;149:392-400.

20. Tilling K, Sterne JAC. Capture-recapture models including covariate effects. Am J Epidemiol 1999;149:392-400.

21. Maldonado G, Greenland S. Simulation study of confounder-selection strategies. Am J Epidemiol 1993;138:923-36.

22. LaPorte RE, Dearwater SR, Chang Y-F et al. Efficiency and accuracy of disease monitoring systems: Applications of capture-recapture methods to injury monitoring. Am J Epidemiol 1995;142:1069-77.

23. Baldovin T, Lazzari R, Cocchio S et al. Invasive meningococcal disease in the Veneto region of Italy: a capture-recapture analysis for assessing the effectiveness of an integrated surveillance system. BMJ Open 2017;7:e012478.

24. Jansson A, Arneborn M, Ekdahl K. Sensitivity of the Swedish statutory surveillance system for communicable diseases 1998-2002, assessed by the capture-recapture method. Epidemiol Infect 2005;133:401-7.

25. Berghold C, Berghold A, Fülöp G, Heuberger S, Strauss R, Zenz W. Invasive meningococcal disease in Austria 2002: assessment of completeness of notification by comparison of two independent data sources. Wien Klin Wochenschr 2006;118:31-5.

26. Gibson A, Jorm L, McIntyre P. Using linked birth, notification, hospital and mortality data to examine false-positive meningococcal disease reporting and adjust disease incidence estimates for children in New South Wales, Australia. Epidemiol Infect 2015;143:2570-9.

27. Vázquez J A, Taha M K, Findlow J, Gupta S, Borrow R. Global Meningococcal initiative: guidelines for diagnosis and confirmation of invasive meningococcal disease. Epidemiol Infect 2016;144:3052-7.

28. Ratnayake R, Allard R. Challenges to the surveillance of meningococcal disease in an era of declining incidence in Montréal, Quebec. Can J Public Health 2013;104:e335-e339.

29. O'Lorcain P, Bennett DE, Morgan SL et al. A retrospective assessment of the completeness and timeliness of meningococcal disease notifications in the Republic of Ireland over a 16-year period, 1999-2015. Public Health 2018;156:44-51.

30. Carmona G, Vilaró M, Ciruela P et al. Hepatitis A surveillance: sensitivity of two information sources. BMC Infect Dis 2018;18:633.

\section{Figures}




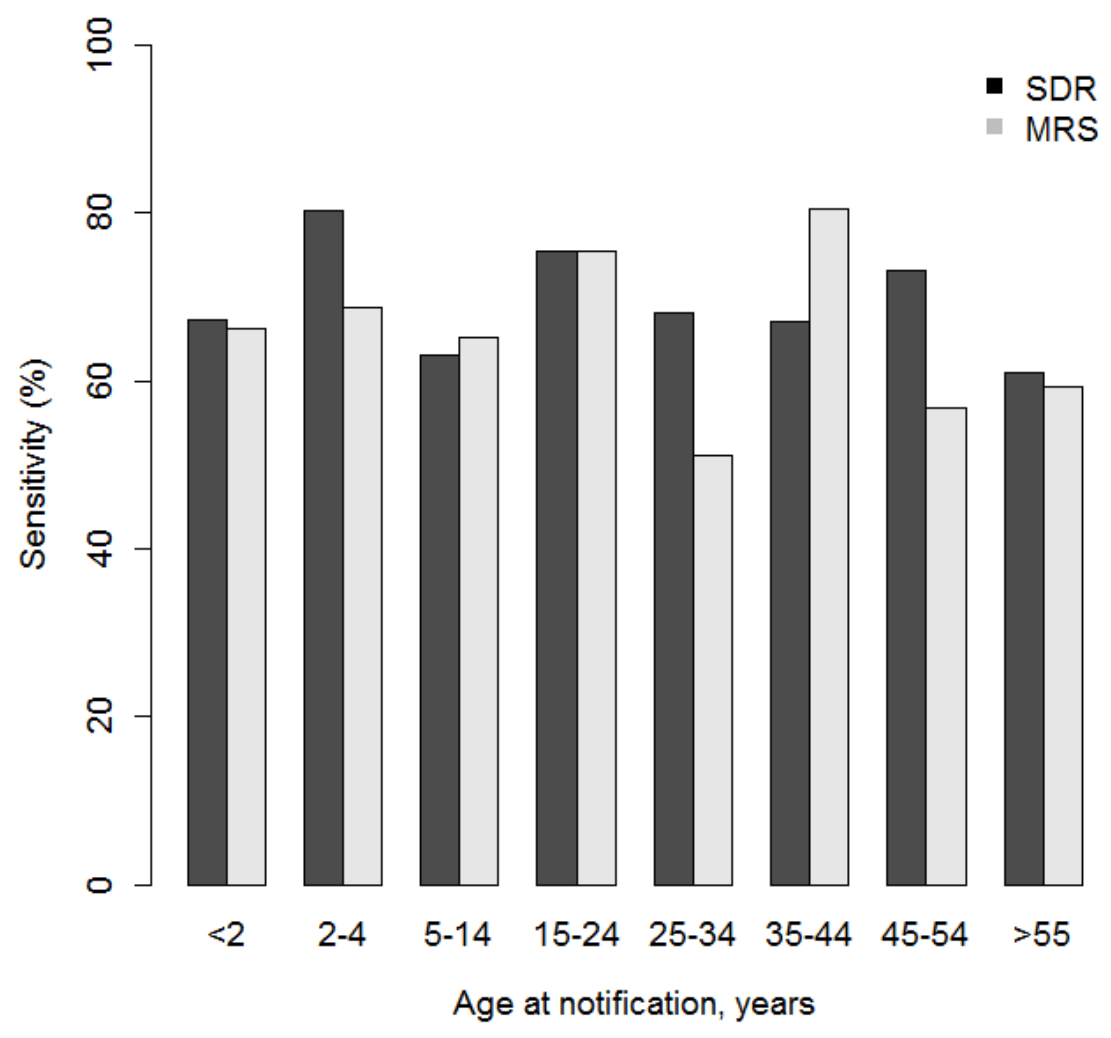

Figure 1

Sensitivities of the SDR and MRS stratified by age groups. Catalonia 2011-2015

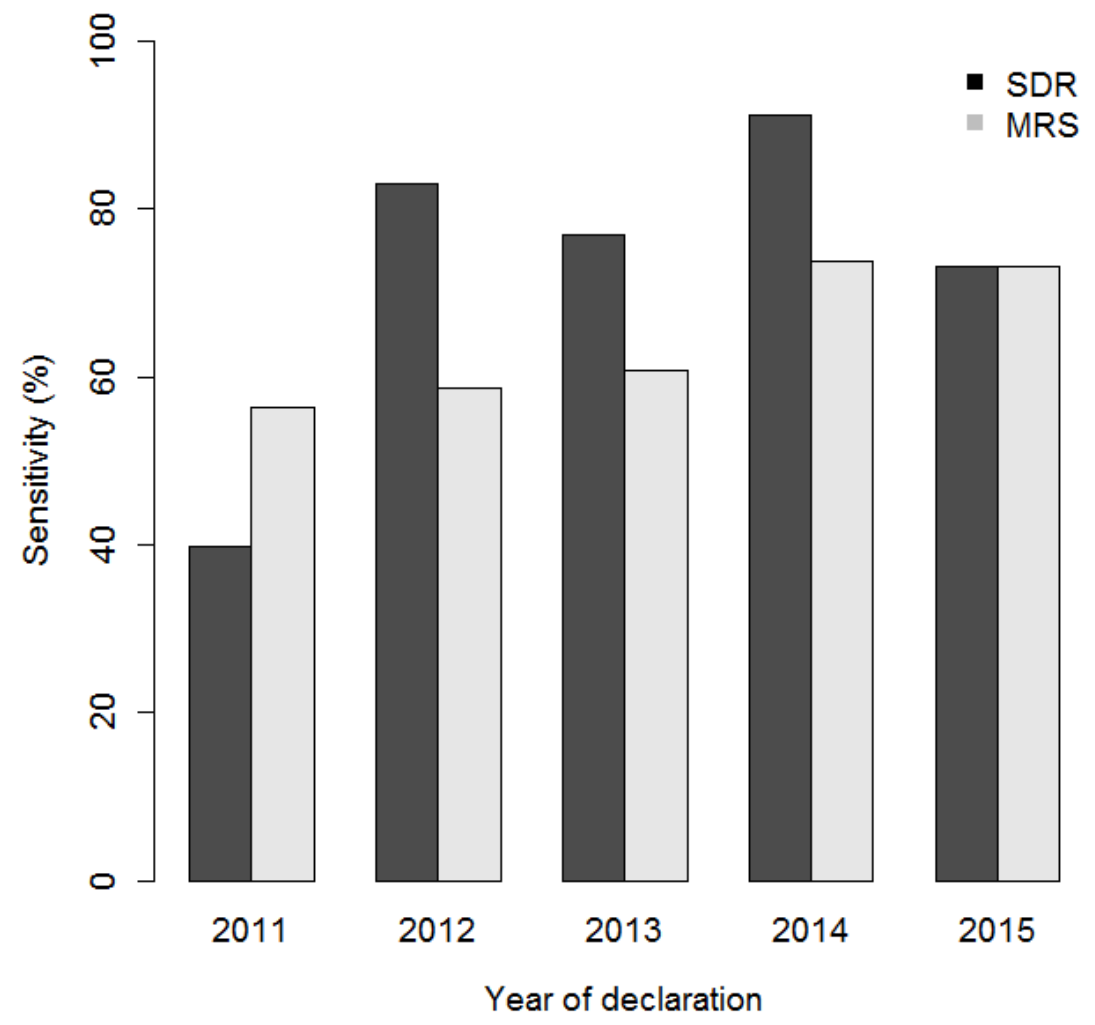


Figure 2

Sensitivities of the SDR and MRS stratified by year of reporting, Catalonia 2011-2015

\section{Supplementary Files}

This is a list of supplementary files associated with this preprint. Click to download.

- SupplementarymaterialPC.docx 